\title{
RESPONSE OF LAYING HENS TO BIO- DEGRADED PALM KERNEL CAKE BASED DIETS
}

\author{
Mosobalaje, M.A., \\ Department of Animal Health and Production, \\ Oyo State College of Agriculture and Tech. Igboora, \\ Abu, O.A., Tewe O.O. \\ Department of Animal Science, \\ University of Ibadan, Ibadan \\ Adedoyin A.A. \\ Department of Agric. Educ. \\ Oyo State College of Education Lanlate, Oyo State
}

\begin{abstract}
Undegraded Palm Kernel Cake (UPKC) and Degraded Palm Kernel Cake (DPKC) were used in eight week feeding of layers at $0 \%, 10 \%, 20 \%$ and $30 \%$ inclusion level. One hundred and twenty, 32 week old Isa brown layers were randomly allotted to four experimental diets with three replicates of ten birds each. Pure culture of Aspergilius niger mycelium was inoculated on autoclaved palm kernel cake by Solid State Fermentation (SSF) method for ten days and used as Degraded Palm Kernel Cake (DPKC). Proximate analysis was carried out on the DPKC and UPKC, and also on the feed. Six weeks into the experiment, three birds were selected from each of the replicate for metabolic trial. The droppings were collected daily, weighed, dried and analysed for proximate content. Parameters considered included feed intake, Hen Day Production (HDP), egg weight, weight gain, Feed Conversion Ratio (FCR), mortality, economy of production and nutrient digestibility. Crude protein, gross energy, NFE and ether extract of degraded PKC increased by $6.88 \%, 9.33 \%, 4.90 \%$ and $7.80 \%$ respectively while fibre content reduced by $4.08 \%$ and ash context by $4.37 \%$. Results on performance of birds revealed that no significant $(\mathbf{P}>\mathbf{0 . 0 5})$ differences were observed for egg production, egg weight and feed conversion ratio. Feed intake of birds fed $30 \%$ DPKC was significantly $(\mathbf{P}>\mathbf{0 . 0 5})$ lower than other treatments. However, weight gain of birds fed $30 \%$ UPKC was significantly
\end{abstract}

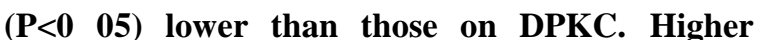
$(\mathbf{P}<\mathbf{0 . 0 5})$ nitrogen retention, crude fibre digestibility and metabolizable energy were recorded for birds fed DPKC diets compared to those on $30 \%$ UPKC. With better nutrient utilization and weight gain, DPKC could be included at up to $30 \%$ in layer ration.

Keywords: Aspergillus niger, Biodegration, Nutrient utilization, Laying performance and Palm kernel cake

\section{INTRODUCTION}

Palm Kernel Cake (PKC), a by-product of oil palm processing is abundant in Nigeria, but its poor digestibility limits its inclusion in livestock feeds especially in monogastric nutrition (Onifade and Babatunde, 1999). Inclusions of high level of this agro-industrial by-product and others in feed formulations for monogastric lead to formation of viscous digesta (Jenkin et al., 1978), increased digesta transit time, low digestibility and palatability (Iyayi and Aderolu, 2004 and Babatunde et al., 1975). There was overall decrease in nutrient digestion and excretion of sticky wet dropping when agro-industrial by-products were fed to monogastrics (Lawal et al., 2010 and Silverside and Bedford, 1999). High fiber levels and presence of antinutritional factors in agro-industrial by-products were implicated in the observations reported. A possible option available for the efficient utilization of these 
by-products is total or partial conversion of the complex plant materials into peptides or amino acids, oligo or monosaccharides (Bachler, 2005; Iyayi and Aderolu, 2004 and Desterhoft, 1991). Methods of improving PKC utilization in livestock feeds include moist heating, grinding and chopping, steam pressure (Dierick et al., 1989 and Longe, 1988) or at least inclusion in rations at minimal level (Panigrahi and Powel, 1991). The application of exogenous enzymes to improve the nutritive quality of agro-industrial byproducts has been reported (Lawal et al., 2010 and Norain, 2002). Another option is the solid-state fermentation of the residues allowing the degradation of complex plant cell wall.

Solid-state fermentation of palm kernel cake will convert complex cell wall materials into peptides or amino acids, oligo or monosacharides (Bachler, 2005 and Iyayi and Aderolu, 2004). Solid state fermentation is the process in which solid substrates are decomposed by known mono or mixed culture of micro-organisms under controlled environmental conditions with the aims of producing high quality products. One of the fungi used in solid state fermentation is Aspergilus niger. It is a cellulotytic mould, which possesses a complete cellulase system and utilizes different cellulosic substrates for the production of protein (Singh et al., 1990). A. niger gave a better colony radial growth, high biomass production and high rate of starch utilization (Abu et al., 1999). The effect of A. niger on palm kernel cake will reduce its fibre content and increase its nutritive value.

Various inclusion levels of PKC have been recommended by various workers. Yeong (1985) recommended $15 \%$ inclusion level for broiler, while Onwudike (1986) revealed that diets containing 28\% PKC can be given to broiler. However, Longe and Adekoya (1988) reported $31.80 \%$ inclusion level of PKC and Radim et al. (2000) recommended 25\% inclusion in layer rations.

This study was designed to access nutritional improvement of A. niger degradation of palm kernel cake and to evaluate effects of feeding degraded palm kernel cake on performance and nutrient utilization of layers. This study assessed biodegraded palm kernel cake for use in layers diet and its effects on performance and nutrient utilization.

\section{MATERIALS AND METHODS}

\section{Organism and Culture Condition}

A culture of Aspergillus niger was obtained from stock culture cultivated on Potato Dextrose Sugar, (PDA) slant at Microbiology Laboratory,
Department of Botany and Microbiology. University of Ibadan, Nigeria.

\section{Fermentation of palm kernel cake}

Four samples of $150 \mathrm{~g}$ each milled palm kernel cake obtained from a palm kernel oil processing plant in Ibadan was placed in each of four, $250 \mathrm{ml}$ conical flask that first plugged with cotton wool and followed by aluminum foil and sterilized at $121^{\circ} \mathrm{C}$ for 15 minutes in autoclave. Then $45 \mathrm{ml}$ sterile water was added to raise the moisture of the substrate to $30 \%$ as described by Ofuya and Nwajuibi (1990). $10 \mathrm{~mm}^{2}$ of inoculum (Aspergillns niger) was added under aseptic condition and then incubated in the oven for 5 days at $30^{\circ} \mathrm{C}$. Each of these sub-culture samples in the conical flasks was then poured into $10 \mathrm{~kg}$ milled sterilized, moistened palm kernel cake and mixed thoroughly with gloved hands. It was then incubated in the black nylon bag for 10 days and then turning was done every alternate days. The samples were oven dried and stored for use as degraded palm kernel cake (DPKC).

\section{FEEDING AND METABOLIC TRIALS}

One hundred and twenty, 32-week old Isa brown hybrid layers were randomly allotted to four experimental diets as shown in table 1 in a completely randomized design. There were thirty birds per treatment with three replicates each. Feed and water were supplied ad libitum. The feeding trial lasted for eight weeks. Six weeks into the experiment, three birds were selected from each of the replicate for metabolic trial. A 3day adjustment period was allowed. After then the birds were offered $150 \mathrm{~g}$ of the experimental diet for three days. Remnants were recorded everyday. Flat trays covered with aluminum foil were placed under each cage compartment. The droppings were collected daily using the total collection method. The collections were weighed, dried and stored for laboratory analysis. Parameters considered included feed intake, hen day production, egg weight, weight gain. Feed Conversion Ratio (FCR), mortality, economy of production and nutrient digestibility. Data collected were subjected to descriptive statistics and Analysis of Variance (ANOVA) using SAS (1997). Where differences exist between means, Duncan multiple range test was used to separate the means. 
International Journal of Engineering Applied Sciences and Technology, 2019

Vol. 4, Issue 4, ISSN No. 2455-2143, Pages 317-322

Published Online August 2019 in IJEAST (http://www.ijeast.com)

\section{RESULTS AND DISCUSSION}

Table 2 showed proximate composition of UPKC and DPKC. The crude protein was raised from $15.98 \%$ in UPKC to $17.02 \%$ in DPKC. The microbes used $(A$. niger) utilized Non Starch Polysaccharides (NSPs) in PKC to release microbial protein which increased crude protein content of the substrate (Liu and Baidoo, 2005). The increase in crude protein content was lower than value reported by Bachtar (2005) who observed upgraded final protein content of fermented cassava products to vary between $16.5 \%-18.5 \%$. Utilization of NSP in PKC also released intracellular soluble carbohydrate and hence increased gross energy was observed in DPKC. Gross energy of DPKC was $3.73 \mathrm{Cal} / \mathrm{kg}$ as compared to $3.41 \mathrm{Cal} / \mathrm{kg}$ in UPKC. This confirmed the report of Iyayi and Aderolu (2004) that solid state fermentation increased energy levels of degraded palm kernel cake. Crude fibre content decreased from $7.21 \%$ to $6.88 \%$. This was due to metabolic activities of the fungus on cell wall material of PKC (Desterhoft et al., 1991). Ether extract was increased from $3.97 \%$ to $4.28 \%$ contrary to Abu et al. (1997) that observed decrease in lipid content of sweet potato after degradation. Table 3 showed proximate composition of the diets, the values were similar $(\mathrm{P}>0.05)$.

\section{PERFORMANCE OF LAYERS FED DEGRADED PKC}

Feed intake of birds fed 30\% DPKC was significant $(\mathrm{P}<0.05)$ and lowest $(118.64 \mathrm{~g} / \mathrm{bird} /$ day $)$ compared to all other experimental diets as shown in table 4 , while the highest value was recorded for birds fed 30\% UPKC $(122.15 \mathrm{~g} / \mathrm{bird} / \mathrm{day})$. The amount of feed consumed is attributable primarily to the energy level of the ration (Leeson and Summer, 1997). Metabolic activities of the fungus increased energy level of $30 \%$

DPKC containing diet and hence reduced feed intake. Egg production of layers on all the experimental diets was similar $(\mathrm{P}>0.05)$. Birds on $30 \%$ DPKC recorded the highest $(87.52 \%)$ value and birds on $20 \%$ DPKC had the lowest value $(85.31 \%)$. This result confirmed Longe and Adekoya (1988) and Onwuidike (1986) that up to $30 \%$ inclusion level of PKC will not adversely affect performance of layer.

Results on FCR and egg weight were similar ( $\mathrm{P}>0.05)$. Values recorded for 30\% UPKC and 10\%-30\% DPKC were 4.20 and $55.8 \mathrm{~g} ; 4.19$ and $58.20 \mathrm{~g} ; 4.27$ and $56.59 \mathrm{~g}$; 4.06 and $57.61 \mathrm{~g}$, respectively. Mortality record was zero. This shows that toxic effects of A. niger was reduced to safe level through drying. Proper drying after degradation is very important because A. niger can cause aspergillosis because of its ability to produce carcinogenous toxins (Riper, 1974.)

Average daily weight gain of birds fed 30\% UPKC $(0.56 \mathrm{~g} /$ day $)$ was significantly $(\mathrm{P}<0.05)$ lower than the control diet (36g/day), 10\%, 20\% and 30\% DPKC (3.9g/day, $2.36 \mathrm{~g} /$ day and $3.38 \mathrm{~g} /$ day, respectively). Weight gain increased with increased in DPKC inclusion level. Poor nutrient utilization of UPKC containing diets was the reason for progressive poor weight gains (Babatunde et al., 1975).

\section{NUTRIENT UTILIZATION}

Table 5 showed nutrient utilization of birds fed the experimental diets. Results obtained revealed that NFE digestibility and ether extract retention were similar ( $>0.05)$ for all the experimental diets and the values ranged between $87.25 \%$ and $90.29 \%$ and $83.63 \%$ and $87.61 \%$, respectively. Nitrogen retention and energy utilization of birds fed $30 \%$ DPKC were significantly $(\mathrm{p}<0.05)$ higher than those on $30 \%$ UPKC. Poor nutrient utilization of birds fed undegraded PKC was due to high fibre content of PKC that was reported to reduce nutrient utilization (Babatunde et al., 1975; Kenelly and Aheme, 1980; Rotenberg and Anderson, 1980 and Ogbonna et al., 1988). Solid state fermentation degraded cell wall material of PKC and consequently released intracellular nutrient and also eliminated antinutritional factors and physiological effects of NSP (Graham and Anan, 1991; Annision and Choct, 1991). Better nutrient utilization of birds fed degraded PKC might also due to reduction in intestinal viscocity (Silverside and Beldford, 1999) which improved digesta transit time. Significant weight gain of birds fed degraded PKC was as a result of better nutrient utilization compared to undegraded PKC.

\section{CONCLUSION}

Solid state fermentation of palm kernel cake improved its nutritive value. Egg production and feed conversion ratio of birds fed undegraded and degraded palm kernel cake were not adversely affected. However, degradation of palm kernel cake through solid state fermentation significantly affected feed intake and weight gain. Lower feed intake and better weight gain as a result of better nutrient utilization will support long term feeding of layers with degraded PKC. 
International Journal of Engineering Applied Sciences and Technology, 2019

Vol. 4, Issue 4, ISSN No. 2455-2143, Pages 317-322

Published Online August 2019 in IJEAST (http://www.ijeast.com)

\section{ACKNOWLEDGEMENTS}

Microbiology Laboratory, Department of Botany and Microbiology. University of Ibadan, Nigeria is appreciated for releasing the Aspergillus niger used. I also appreciate staff of Microbiology Unit of Department of Animal Science, University of Ibadan for their cooperation.

\section{REFERENCES}

1. Abu, O.A., Losel, D.M.; Onifade, A. A. and Tewe , O.O. (1999). Suitability of screened fungi for solid state fermentation, Trop. Anim. Prod. Invest. 2: 1 - 4 .

2. Abu, O.A.; Losel, D.M. and Tewe, 0.0. (1997). Solid state fermentation of sweet potato using two monoculture fungi: Changes in Protein, Fatty acid. Proc. of 2nd Annual Conference of Animal Science Association of Nig. $219-224$.

3. Annison, G. and Choct, M. (1991). Antinutritive activities of cereal non-starch polysaccharides in broiler diets and strategies minimizing their effects. World Poultry Sci. J. 232-242.

4. Babatunde, G.M., Babatunde, L,F. Odumosu, 0. and Oyenuga, V.A. (1975). Palm kernel meal as the major protein concentrate in the diets of pigs in the tropics. J. Sci. Food 26: 1279 - 1291.

5. Bachtar, B. (2005). Improvement of nutritive value of crop by-product using bioprocess techniques and their uses for animal. J. Feed Technology 21:1-5

6. Classen, H.L. (1996). Cereal grain starch and exogenous enzymes in poultry diets. Animal Feed Sci. Techn. 62: 21 - 27.

7. Cowan, W.D. Korsbak, A. Hastrup, T. and Rasmussen, O. (1996). Influence of added microbial enzymes on energy and protein availability of selected feed ingredient. Animal Sci. Technology. 60: 311 - 319.

8. Dusterhoft, E.M.., (1993). Characterisation and enzymic degradation of non-starch polysaccharides in lingnocellulosic by-products: A study of sunflower meal and palm kernel meal. Ph.D. thesis, Department of Food Chemistry and Microbiology, Agricultural University, Wageningen, Germany.

9. Dusterhoft, E.M.; Voragen, A.G.T. and Engels, P.M. (1991). Non-starch polysaccharides from sunflower (Helianthus annus) meal and palm kernel (Elaeis guineensis) meal - Preparation of cell wall material and extraction of polysaccharides fractions. J. Sci. Food Agric. $55: 411$ - 422.

10. Graham, H. and Aman. P. (1991) Nutritional aspects of dietary fibre.Animal Feed, Sci. Technol,32: 143-158.

11. Iyayi, E.A. and Aderolu, Z. A. (2004). Enhancement of the feeding value of some agro industrial by products for laying hens after their solid fermentation with Trichoderma vivide. Afri. Biotech J; 182185.

12. Jenkins, D.,J.,.A., Wolever, T.M.J. and Leeds, A.R.B. (1978). Dietary fibre, fibre analogue and glucose tolerance: importance of viscosity. British Med. J. 1(6124):1392-1394.

13. Kennelly, J.J. and Aherne, F.X. (1980). The effects of fibre in diets formulated to certain different levels of energy and protein on digestibility coefficient in swine. Can. J. Anim. Sci. 60:717 - 726..

14. Lawal, T.E:, Iyayi, E.A, Adeniyi, B.A and Adaramoye O.A. (2010). Biodegradation of palm kernel cake with multi enzyme complexes from fungi and its feeding value for broilers. International Journal of Poultry Sciences. 9(7) 695-701.

15. Leeson, S. and Summer, J. D. (1997). Commercial poultry nutrition. $2^{\text {nd }}$ Edition, University Books, Ontario Canada.

16. Longe O.G. (1988). Meeting the energy needs of non-ruminants from non-convention feed resources in Nigeria. Paper presented at Rural Management Training Institute. (RMTI). Ilorin. November, 21 - 25, 1988.

17. Longe, O.G. and Adekoya, O.F.A. (1988). Response of laying hens to different inclusion rates of palm kernel meal and vegetable oil. Nig. J. Anim. Prod. 15:111 117.

18. Noraini, S.Suraini, A.A and Gan, S.H. (2002). Proc of the $24^{\text {th }}$ Malaysian Soc. Animal Production. Pulan pinang p.39-40

19. Ofuya, C 0. and Nwajiuba, C.J. (1990). Fermentation of cassava peels for the production of cellulolytic enzyme. J. Applied Bacter. 68:171-177.

20. Ogbonna, J.U., Longe, O.G. and Legel, S. (1988). Investigation of the digestibility of proximate composition in commercial palm kernel meal in broiler chick rations. Arch. Anim. Nutr. 3:215 -219.

21. Onifade, A.A. and Babatunde, G.M. ()1999. Comparison of the utilization of palm kernel meal. brewer dry grain and maize offal by 


\section{International Journal of Engineering Applied Sciences and Technology, 2019 \\ Vol. 4, Issue 4, ISSN No. 2455-2143, Pages 317-322 \\ Published Online August 2019 in IJEAST (http://www.ijeast.com)}

broider chicks. Br. Poultry Science. 39:245250

22. Onwudike, O.C. (1986). Palm kernel meal as feed for poultry. 3. Replacement of groundnut by PKM in layer diets. Anim. Feed. Sci. Technol. 16:195-202.

23. Panigrahi, S. and Powell C.J. (1991). Effects of high rates of inclusion of palm kernel, in broiler chick diets. Anim. Feed Sci. Technol. 34:37-42.

24. Radim, D., Alimon, A.R and Yusnita, Y. (2000). Proc. of the 22nd Malaysian Soc. Animal Production. Kota Kinabalu P.177178.

25. Raimbault, M; Revan, S., Pina F. and Villalobos, P. (1985). Protein enrichment of cassava by solid state substrate fermentation using molds isolated from traditional food. J. Ferment Technol Vol. 63, No. 4. 395-399.

26. Ripper, J. W. (1974). Medical mycology. W.B Saunder Co. Philadelphia pg. 589.

27. Rotenbery, S. and Anderson, J. O (1980). The effect of dietary citrus pectins of fatty acid balance and on the fatty acid content on the liver and small intestine in rats. Acta. Agric Scand. 33: 321-325

28. SAS, (1997). Statistical analysis system users guide. SAS/STAT $6^{\text {th }}$ edition SAS Institute Inc. Cary NC, USA.

29. Silversides, F.G and Bedford, M. R. (1999). Soluble non-starch polysaccharides, enzymes, and gut viscosity - is there a connection? World Poult. 15 (5) 17 \& 18.

30. Singh, A.; Abidi, A.B., Darmwal, N.S and Agrwal, A.K. (1990). Saccharification of cellulosic substrates by Aspergillus niger Cellulose. World J. Microbiol and Biotechnol. 6: 333-338.

31. Topping, D.L. (1991). Soluble fibre polysaccharides: Effects on plasma cholesterol and colonic fermentation. Nutri. Rev. 49 195203.

32. Yeong, S.W . (1985). Palm oil by products as feed for poultry. Proc National Symposium on oil palm by Products for cyro-based Industries. November 5-6, 1985 Malaysia pp. 175-186.

Table 1: The Gross Composition of the Experimental Diets

\begin{tabular}{lllll}
\hline Ingredients & $\mathbf{3 0 \%}$ UPKC & $\mathbf{1 0 \%}$ DPKC & $\mathbf{2 0 \%}$ DPKC & $\mathbf{3 0 \%}$ DPKC \\
\hline Maize & 38 & 38 & 38 & 38 \\
Palm oil & 3.0 & 3.0 & 3.0 & 3.0 \\
Wheat offal & 6.0 & 6.0 & 6.0 & 6.0 \\
Groundnut cake & 10 & 10 & 10 & 10 \\
Fish meal 72\% & 2.6 & 2.6 & 2.6 & 2.6 \\
Undegraded PKC & 30 & 20 & 10 & - \\
Degraded PKC & - & 10 & 20 & 30 \\
Oyster shell & 7.5 & 7.5 & 7.5 & 7.5 \\
DCP & 2.2 & 2.2 & 2.2 & 2.2 \\
Premix & 0.25 & 6.25 & 0.25 & 0.25 \\
Salt & 0.25 & 0.25 & 0.25 & 0.25 \\
Lysine & 0.1 & 0.1 & 0.1 & 0.1 \\
DL Methionine & 0.1 & 0.1 & 0.1 & 0.1 \\
Total & $\mathbf{1 0 0}$ & $\mathbf{1 0 0}$ & $\mathbf{1 0 0}$ & $\mathbf{1 0 0}$ \\
Calculated value Energy Kcal/Kg & 2599.66 & 2599.66 & 2599.66 & 2599.66 \\
Crude protein & 16.41 & 16.4 & 16.4 & 16.4 \\
\hline
\end{tabular}

UPKC - Undegraded Palm Kernel Cake;

DPKC - Degraded Palm Kernel Cake; DCP - Dicalcium phosphate

* Premix composition per kg: Vitamin $\mathrm{A}=4,000,000 \mathrm{I}$.U, Vitamin $\mathrm{D}_{3}=1,200,000 \mathrm{I}$.U, Vitamin $\mathrm{E}=3,200 \mathrm{IU}$, Vitamin $\mathrm{K}=800 \mathrm{mg}$, Vitamin $\mathrm{B}_{1}=800 \mathrm{mg}$, Vitamin $\mathrm{B}_{2} 200 \mathrm{mg}$, Vitamin $\mathrm{B}_{6=} 480 \mathrm{mg}$, Vitamin $\mathrm{B}_{12}=4,800 \mathrm{mg}$, Biotin $=12 \mathrm{mg}$, Niacin $4,000 \mathrm{mg}$, Panthothenic acid $=2,800 \mathrm{mg}$, Folic acid $=240 \mathrm{mg}$, Choline chloride 2,000mg, Vit. $\mathrm{C}=4,000 \mathrm{mg} ; \mathrm{Mn}=32,000 \mathrm{mg} \mathrm{Mg}=40,000 ; \mathrm{Cu}=3,200 \mathrm{mg} ; \mathrm{Zn}=20,000 ; \mathrm{C}=180 \mathrm{mg} ; 1=80 \mathrm{mg} ; \mathrm{Se}=40 \mathrm{mg}$ 
International Journal of Engineering Applied Sciences and Technology, 2019

Vol. 4, Issue 4, ISSN No. 2455-2143, Pages 317-322

Published Online August 2019 in IJEAST (http://www.ijeast.com)

Table 2: Proximate composition of Undegraded and degraded PKC

\begin{tabular}{lll}
\hline Composition (\%) & \multicolumn{1}{c}{ Undegraded palm kernel cake } & Degraded palm kernel cake \\
\hline Dry matter & 88.43 & 90.8 \\
Crude protein & 15.98 & 17.02 \\
Ether extracts & 3.97 & 4.28 \\
Crude fibre & 7.21 & 6.88 \\
Ash & 5.93 & 4.57 \\
NFE & 55.34 & 58.05 \\
Phosphorus & 0.50 & 0.45 \\
Gross energy (Kcal/g) & 3.41 & 3.73 \\
\hline
\end{tabular}

Table 3: Proximate composition of the experimental diet

\begin{tabular}{lllll}
\hline Parameters \% & $\mathbf{3 0 \% U P K C}$ & $\begin{array}{c}\text { Dietary } \\
\mathbf{1 0 \% D P K C}\end{array}$ & $\begin{array}{l}\text { Treatments } \\
\text { 20\%DPKC }\end{array}$ & 30\%DPKC \\
\hline Dry matter & 89.84 & 89.98 & 90.17 & 90.57 \\
Crude protein & 16.41 & 16.75 & 16.89 & 16.97 \\
Either extracts & 4.02 & 4.27 & 4.49 & 4.52 \\
Crude fibre & 6.67 & 6.24 & 6.03 & 6.04 \\
Ash & 9.19 & 11.12 & 11.61 & 9.52 \\
NFE & 53.55 & 51.60 & 51.17 & 53.52 \\
Calcium & 3.76 & 3.97 & 3.47 & 4.02 \\
Phosphorus & 0.46 & 0.47 & 0.49 & 0.51 \\
Gross Energy Kcal & 3.40 & 3.49 & 3.64 & 3.72 \\
\hline
\end{tabular}

Table 4: Performance Characteristics of birds fed experimental diets

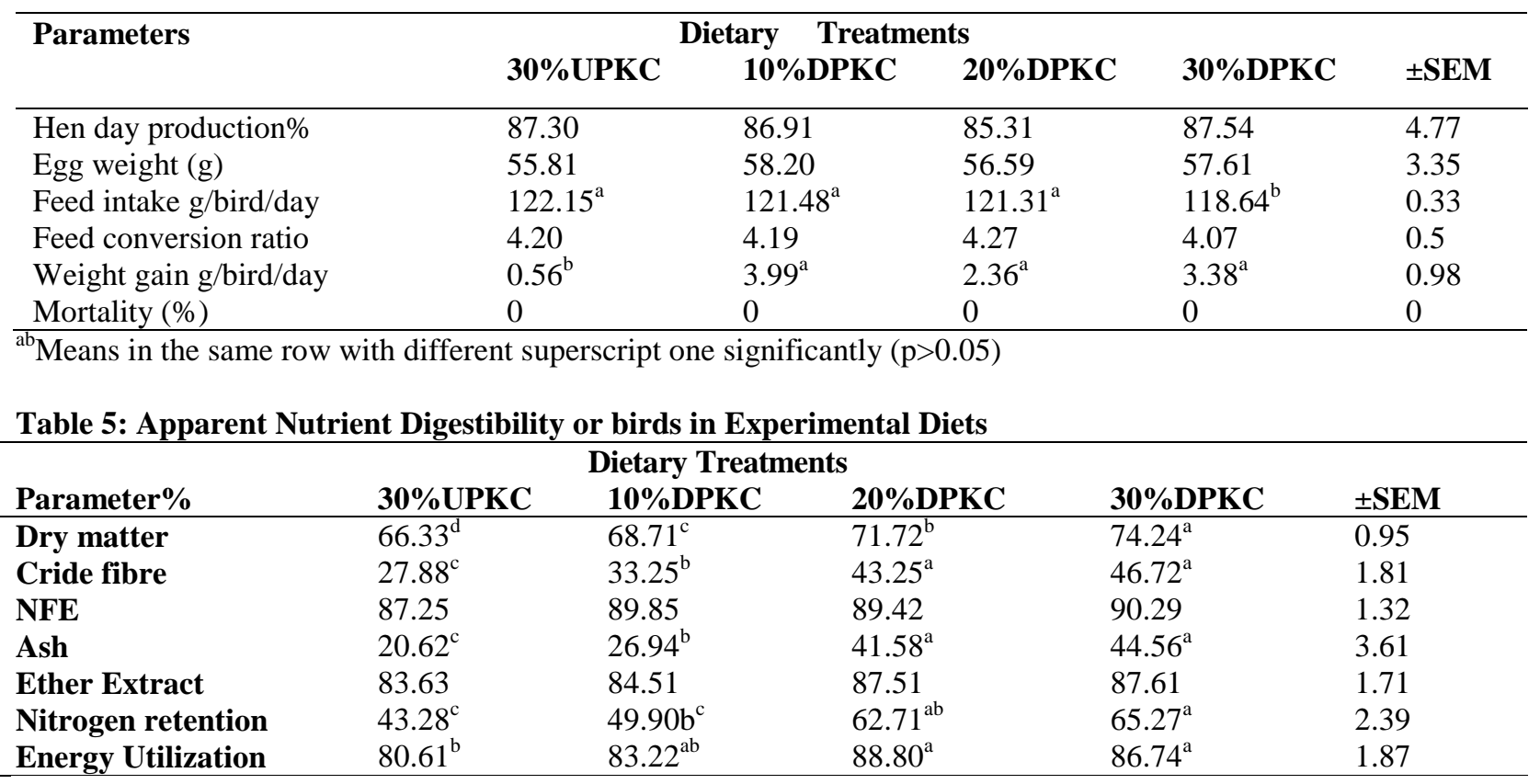

